\title{
Modern Rice (Oryza sativa L.) Production Potentiality through a Sorts of Management Practice
}

\section{Atik Ahmed ${ }^{1 *}$, Md Masud Rana Parvej ${ }^{2}$, Md Hafiz All Amin ${ }^{3,4}$, Alok Kumar Paul ${ }^{5}$ and Md. Asaduzzaman Khan ${ }^{5}$}

${ }^{1}$ Upazila Agriculture Officer, Department of Agricultural Extension, Bangladesh ${ }^{2}$ Officer (Chemicals), Padma Oil Company Limited, Bangladesh

${ }^{3}$ Sustainable Energy Management, Faculty of Environmental Management, Prince of Songkla University, Hat Yai, 90110, Songkhla, Thailand

${ }^{4}$ Associate Professor, Department of Agroforestry and Environment, Faculty of

Agriculture, Hajee Mohammad Danesh Science and Technology University,

Dinajpur-5200, Bangladesh

${ }^{5}$ Professor, Department of Soil Science Sher-e-Bangla Agricultural University (SAU),

Dhaka, Bangladesh

*Corresponding Author: Atik Ahmed, Upazila Agriculture Officer, Department of Agricultural Extension, Bangladesh. E-mail: a.atik44@gmail.com
Received: March 08, 2021

Published: April 16, 2021

(C) All rights are reserved by Atik Ahmed., et al.

\begin{abstract}
The purpose of the research is to evaluate the production performance of transplanted modern rice using organic manure and inorganic fertilizer with water management. The research activity was completed by following Two (2) factors split plot design (SPD) with three replications. The treatments were factor A: two irrigations $\left(\mathrm{I}_{1}=\right.$ Continuous flooding; $\mathrm{I}_{2}=$ Alternate wetting and drying) arranged in the main plots, whereas factor B: 8 different doses of fertilizer + manure $\left(\mathrm{T}_{0}:\right.$ Control, $\mathrm{T}_{1}: 100 \% \mathrm{~N}_{100} \mathrm{P}_{15} \mathrm{~K}_{45} \mathrm{~S}_{20} \mathrm{Zn}_{2}, \mathrm{~T}_{2}: 50 \%$ NPKSZn +5-ton cowdung/ha, $\mathrm{T}_{3}:$ 70\% NPKSZn + 3-ton cowdung/ha, $\mathrm{T}_{4}:$ 50\% NPKSZn + 5-ton compost/ha, $\mathrm{T}_{5}: 70 \%$ NPKSZn +3-ton compost/ha, $\mathrm{T}_{6}: 50 \% \mathrm{NPKSZn}+3.5$-ton poultry manure/ha and $\mathrm{T}_{7}: 70 \% \mathrm{NPKSZn}+2.1$-ton poultry manure/ha) settled in the subplots. The finding of the research revealed that the irrigation practices had not any significant effect but different doses of fertilizer and manure had significant outcomes on rice production. The highest numbers of effective tillers/hill (9.13), plant height (119.79 $\mathrm{cm})$, panicle length (27.96 cm), 1000 grain wt. (21.67g), grain yield (5.12 t/ha) and straw yield (10.1 t/ha) were found from (50\% NPKSZn plus 5-ton cowdung/ha), (70\% NPKSZn plus 3-ton cowdung/ha), (70\% NPKSZn plus 3-ton compost/ha), (50\% NPKSZn plus 5-ton compost/ha), (70\% NPKSZn plus 2.1-ton poultry manure/ha) and (100\% $\mathrm{N}_{100} \mathrm{P}_{15} \mathrm{~K}_{45} \mathrm{~S}_{20} \mathrm{Zn}_{2}$ ), respectively. The grain yield percent increase $(38.3 \%)$ was recorded from (70\% NPKSZn plus 2.1-ton poultry manure/ha). The grain yield was higher because of organic +inorganic fertilizers as compared to chemical fertilizer. Moreover, the combined result of irrigation with fertilizer and manure was significantly influenced in yield. The highest grain yields (5.78 $\mathrm{t} / \mathrm{ha}$ ) were recorded from (Alternate wetting and drying with 70\% NPKSZn plus 2.1-ton poultry manure/ha). The transplanted rice grain and straw nutrient concentrations were significantly affected by the application of fertilizer and manure. Finally, it can be recommended (70\% NPKSZn plus 2.1-ton poultry manure/ha) for effective production of modern transplanted rice cultivation.
\end{abstract}

Keywords: Nutrient Accumulation; Chemical Fertilizer; Organic Manure; Irrigation; Grain Yield

\section{Abbreviations}

\%: Percent; @: At the Rate; AEZ: Agro-Ecological Zone; ANOVA: Analysis of Variance; BARI: Bangladesh Agricultural Research In- stitute; BBS: Bangladesh Bureau of Statistics; CEC: Cation Exchange Capacity; cm: Centimetre; CV\%: Percentage of Coefficient of Variation; DMRT: Duncan's Multiple Range Test; et al.: and Others; Etc: 
Etcetera; FAO: Food and Agricultural Organization; g: Gram; hr:: Hours; Kg/ha: Kilograms Per Hectare; Kg: kilogram; LAD: Leaf Area Diseased; M: Meter; MSE: Mean Square of the Error; No.: Number; ppm: Parts per Million; SE: Standard Error; Wt.: Weight

\section{Introduction}

Food is the prime fundamental demand for human beings in the world. The food demand will increase gradually day after day in future. More than two third of the world's population are presently living in the developing countries where agricultural production is not sufficient to meet the need of country [1]. Bangladesh, the most densely populated agricultural-based country is the fourth largest rice growing zone of the world. As the arable land is day by day decreased, the pressure goes on agriculture mainly in rice (Oryza sativa L.) crop production. Rice is the main food for almost all, and it has a huge impact on the agrarian economy in $3^{\text {rd }}$ world countries like Bangladesh. There are three distinct rice growing season in a year, among these, transplanted Aman rice contributes to $35.47 \%$ of the total rice production in the country [2]. On an average, 80\% of total cultivating area is occupied by intensively rice cultivation. It alone creates about $95 \%$ of the country's food grain output. Truly, the rice production is minimum as compare to Japan (6.22 t/ha) and South Korea (7.00 t/ha), respectively [3]. Instead, the need for increased rice production has reached an alarming height to satisfy the growing demand.

The exhaustion of soil nutrients is a big obstacle for higher crop yields [4]. A greater land use, particularly in intensive cropping systems, depletes available nutrients in the soil. Farmers use a total of $102 \mathrm{~kg}$ of nutrients per hectare per year $(70 \mathrm{~kg} \mathrm{~N}+24 \mathrm{~kg} \mathrm{P}+$ $6 \mathrm{~kg} \mathrm{~K}+2 \mathrm{~kg} \mathrm{~S}$ and $\mathrm{Zn}$ ) while harvesting is approximately $200 \mathrm{~kg}$ $\mathrm{ha}^{-1}[5]$. The soil with crops has less than 1.5 per cent organic matter whereas healthy agricultural soils can have at least 2 per cent organic matter [6]. In addition, this significant soil portion is decreasing over time due to intense agriculture and higher dosage of chemical fertilizers with little or no organic manure in the farmer's field. Furthermore, the accelerated mineralization of soil organic matter happens owing to the warm tropical climate of Bangladesh. Without cycling of organic matter, nutrients cannot move freely in the soil, thereby resulting in slower nutrient use. unless a proper effort is made to enhance and maintain soil organic matter levels, production will not be feasible or maintained. It requires a complex range of organic and inorganic nutrients for long-term agriculture to yield high-quality food. Iqbal., et al. [7] views that a successful in- tegration of organic manures and chemical fertilizers will provide greater productivity, as well as the capability to preserve soil fertility and agricultural production. Long-term study at Bangladesh Agricultural Research Institute (BARI) showed that applying cowdung @5 t/ha/year increased rice production while also preventing soil depletion [8]. However, a decent source of nutrients in the soil is poultry manure [9]. It has been shown that $4 \mathrm{t} /$ ha of chicken manure and $60 \mathrm{~kg} \mathrm{~N} / \mathrm{ha}$ of urea provide a crop yield close to that of $120 \mathrm{~kg} \mathrm{~N} /$ ha of urea alone [10]. Organic manure can provide a large amount of plant nutrients so it can lead to crop yields [11]. As a result, in order to achieve a sustainable crop yield without reducing soil productivity, it is important to use fertilizer and manure in tandem.

Soil organic matter increases crop development by enhancing the physicochemical properties of the soil. Regressive organic matter from various AZEs has dropped by approximately by 15 $30 \%$ during the last two decades [12]. Consequently, soil potential cannot be used as the sole output guideline. Earlier in this century, attention was paid to the global environmental issues of using of vermicompost although FYM, and it has changed lately to concentrate on using food waste, fertilizer, manures, and poultry manure. Different fertilizers and manure make land harder and promote biological activity. It's also linked to enzymatic behavior and soil porosity. Organic fertilizer increases normal and intermittent pores in the surface, causing a priming impact in native soil organic matter. To boost soil physical properties and provide vital plant nutrients for better yields, both chemical and organic fertilizers must be used [13]. Irrigation is another important factor for the growth and development of rice plant. According to the Yang., et al. [14] applications of mixed chemical fertilizers with cow dung manure or wheat straw in an alternative wet and dry conditions improved $\mathrm{N}, \mathrm{K}$ and $\mathrm{P}$ absorption by rice plants, as well as 1000 grain weight and grain yield. The above discussion gives the idea that transplanted-Aman rice production can be increased by applying effective management practices. So, it is most important to determine a management practice selection that will play an influential role in rice production. The present research theme is to bring a suitable management scheme that can lead rice cultivation to enhance. Hence, the objective of the experiment is to develop a suitable integrated dose of inorganic fertilizers and manures with water management on the yield, yield components of transplantedAman rice along with improvement of soil fertility. 


\section{Materials and Methods}

\section{Experimental site, soil and plant material}

The experimental research was accompanied in rice cultivating classic silty loam soil at the Sher-e-Bangla Agricultural University Farm, Dhaka, Bangladesh during the transplanted-Aman season, the average temperature ranges from 19.2 to $31.8\left({ }^{\circ} \mathrm{C}\right)$ during experimental period July to October. In the first and second table, the features of the soil are given in relation to both their morphology, as well as their chemical and physical properties. The experimental area's atmosphere is marked by light precipitation connected with a minimum temperature during the field research work. BRRI dhan 32 was selected for the research as tested crop. Bangladesh Rice Research Institute (BRRI) released this variety for transplantedAman season.

\begin{tabular}{|l|c|}
\hline Morphology & Characteristics \\
\hline Location & SAU Farm, Dhaka. \\
\hline Agro-ecological zone & Madhupur Tract (AEZ- 28) \\
\hline General Soil Type & Deep Red Brown Terrace Soil \\
\hline Parent material & Madhupur Terrace. \\
\hline Topography & Fairly level \\
\hline Drainage & Well drained \\
\hline Flood level & Above flood level \\
\hline
\end{tabular}

Table 1: Morphological characteristics of the experimental field [15].

\begin{tabular}{|l|c|}
\hline Characteristics & Value \\
\hline Mechanical fractions: & \\
\% Sand (2.0-0.02 mm) & 22.26 \\
\% Silt (0.02-0.002 mm) & 56.72 \\
\% Clay (<0.002 mm) & 20.75 \\
\hline Textural class & Silt Loam \\
\hline pH (1: 2.5 soil- water) & 5.9 \\
\hline Organic Matter (\%) & 1.09 \\
\hline Total N (\%) & 0.028 \\
\hline Available K (ppm) & 15.625 \\
\hline Available P (ppm) & 7.988 \\
\hline Available S (ppm) & 2.066 \\
\hline
\end{tabular}

Table 2: The soil's original physical and chemical features.

\section{Research design and treatments}

The experimental research followed two factors split plot design (SPD) consisted of three (3) replications. The layout was made distributing two irrigations (continuous flooding and alternate wetting and drying) arranged in main plots and fertilizer + manure treatments to the sub plots. There were 48 plots in total, measuring $2.5 \mathrm{~m} \times 2.0 \mathrm{~m}$ and ails separated plots from each other. A difference of $1.0 \mathrm{~m}$ and $0.5 \mathrm{~m}$ was held between two main plots and two sub plots, respectively. The experimental treatments were as follows-

- Factor A: Irrigation

- $\mathrm{I}_{1}=$ Continuous flooding

- $\quad \mathrm{I}_{2}=$ Alternate wetting and drying.

- Factor B: Fertilizer plus manure

- $\mathrm{T}_{0}=$ Control

- $\mathrm{T}_{1}=100 \% \mathrm{~N}_{100} \mathrm{P}_{15} \mathrm{~K}_{45} \mathrm{~S}_{20} \mathrm{Zn}_{2}$ (Recommended dose)

- $\mathrm{T}_{2}=50 \% \mathrm{NPKSZn}+5$ ton cowdung/ha

- $\mathrm{T}_{3}=70 \% \mathrm{NPKSZn}+3$ ton cowdung/ha

- $\mathrm{T}_{4}=50 \%$ NPKSZn +5 ton compost/ha

- $\mathrm{T}_{5}=70 \%$ NPKSZn +3 ton compost $/$ ha

- $\mathrm{T}_{6}=50 \% \mathrm{NPKSZn}+3.5$ ton poultry manure/ha

- $\mathrm{T}_{7}=70 \% \mathrm{NPKSZn}+2.1$ ton poultry manure/ha.

Treatment combination

- $\quad \mathrm{I}_{1} \mathrm{~T}_{0}=($ Continuous flooding + Control $)$

- $\mathrm{I}_{1} \mathrm{~T}_{1}=$ (Continuous flooding $+100 \% \mathrm{~N}_{100} \mathrm{P}_{15} \mathrm{~K}_{45} \mathrm{~S}_{20} \mathrm{Zn}_{2}$ (Recommended dose)\}

- $\quad \mathrm{I}_{1} \mathrm{~T}_{2}=($ Continuous flooding $+50 \%$ NPKSZn +5 ton cowdung/ha)

- $\mathrm{I}_{1} \mathrm{~T}_{3}=$ (Continuous flooding $+70 \%$ NPKSZn +3 ton cowdung/ha)

- $\mathrm{I}_{1} \mathrm{~T}_{4}=$ (Continuous flooding $+50 \% \mathrm{NPKSZn}+5$ ton compost) ha)

- $\quad \mathrm{I}_{1} \mathrm{~T}_{5}=$ (Continuous flooding $+70 \% \mathrm{NPKSZn}+3$ ton compost) ha)

- $\quad \mathrm{I}_{1} \mathrm{~T}_{6}=($ Continuous flooding $+50 \%$ NPKSZn +3.5 ton poultry manure/ha)

- $\quad \mathrm{I}_{1} \mathrm{~T}_{7}=($ Continuous flooding $+70 \%$ NPKSZn +2.1 ton poultry manure/ha) 
- $\quad \mathrm{I}_{2} \mathrm{~T}_{0}=$ (Alternate wetting and drying + Control $)$

- $\mathrm{I}_{2} \mathrm{~T}_{1}=[$ Alternate wetting and drying $+100 \%$ $\mathrm{N}_{100} \mathrm{P}_{15} \mathrm{~K}_{45} \mathrm{~S}_{20} \mathrm{Zn}_{2}$ (Recommended dose)]

- $\quad \mathrm{I}_{2} \mathrm{~T}_{2}=($ Alternate wetting and drying $+50 \% \mathrm{NPKSZn}+5$ ton cowdung/ha)

- $\quad \mathrm{I}_{2} \mathrm{~T}_{3}=($ Alternate wetting and drying $+70 \% \mathrm{NPKSZn}+3$ ton cowdung/ha)

- $\mathrm{I}_{2} \mathrm{~T}_{4}=($ Alternate wetting and drying $+50 \%$ NPKSZn +5 ton compost/ha)

- $\mathrm{I}_{2} \mathrm{~T}_{5}=($ Alternate wetting and drying $+70 \%$ NPKSZn +3 ton compost/ha )

- $\quad \mathrm{I}_{2} \mathrm{~T}_{6}=$ (Alternate wetting and drying $+50 \%$ NPKSZn +3.5 ton poultry manure/ha)

- $\mathrm{I}_{2} \mathrm{~T}_{7}=$ (Alternate wetting and drying $+70 \%$ NPKSZn +2.1 ton poultry manure/ha).

\section{Field planning and fertilizer application}

The field was first opened by a tractor and extensively equipped by ploughing and cross ploughing with a power tiller, supplemented by a country plough. Laddering assisted with breaking up the clods, and with each ploughing, the ground was leveled. Until transplanting, weeds, stubbles, and crop residues were removed from each plot device. Finally, puddling was used to plan each story. Initial soil samples at $0-15 \mathrm{~cm}$ depth were obtained from multiple locations in the experimental area prior to land preparation. The composite soil sample was air-dried, crushed, and sieved at a size of $2 \mathrm{~mm}$ ( 8 meshes). The soil samples were sieved and stored in a plastic jar for physical and chemical examination. According to the Bangladesh Rice Research Institute, the recommended doses of $\mathrm{N}$ as Urea $192 \mathrm{Kg} / \mathrm{ha}, \mathrm{P}$ as TSP $60 \mathrm{Kg} / \mathrm{ha}$, K as MoP $105 \mathrm{Kg} / \mathrm{ha}, \mathrm{S}$ as Gypsum $68 \mathrm{Kg} / \mathrm{ha}$, Zn as ZnSO $41 \mathrm{Kg} /$ ha for transplanted-Aman rice cultivation. The amount of these fertilizers were measured as per treatments. Until transplanting rice seedlings, maximum doses of TSP, MP, gypsum, and zinc sulphate were added as a basal dose. One-third of the urea was added at the basal before transplanting, one-third at the successful tillering point (30 DAT), and the remaining one-third at the panicle initiation stage (5 DAT) (55 DAT). Cowdung, poultry manure, and compost were the three forms of sustainable manure used. According to the treatments, the rates of manure were $3 \& 5,2.1 \& 3.5$, and $3 \& 5$ ton/ha for cow dung, poultry manure, and compost per plot, respectively. Before the final four days of land planning, cowdung, poultry manures, and compost is added. Table 3 shows the chemical compounds of the manures that were used.

\begin{tabular}{|l|c|c|c|c|}
\hline \multirow{2}{*}{$\begin{array}{l}\text { Sources of organic } \\
\text { manure }\end{array}$} & \multicolumn{4}{|c|}{ Nutrient content } \\
\cline { 2 - 5 } & N (\%) & P (\%) & K (\%) & S (\%) \\
\hline Cow dung & 1.46 & 0.29 & 0.74 & 0.24 \\
\hline Poultry manure & 2.2 & 1.99 & 0.82 & 0.29 \\
\hline Compost & 2.89 & 0.28 & 1.60 & 0.32 \\
\hline
\end{tabular}

Table 3: The chemical properties of the compost, cow dung and poultry manure (Based on oven dry)

\section{Seedlings transplanted}

Rice seedlings were grown utilizing wet-bed techniques. Seeds (95 percent germination) were soaked and incubated for 48 hours before being sown on a well-prepared seedbed at a pace of $5 \mathrm{~kg} /$ ha. Fertilizers were not used during seedling development. Where necessary, proper water and pest control procedures were adopted. Seedlings that were forty days old were gently uprooted from the seedling nursery and transplanted onto a well-drained puddle plot. Two seedlings were used per slope, with a $20 \mathrm{~cm} 20 \mathrm{~cm}$ spacing. After one week of transplanting, all plots were tested for any missed hills, which were filled in as required with extra seedlings.

\section{Intercultural operations}

Intercultural operations were carried out to ensure that the crop grew normally. Plant security measures were implemented as required. T-Aman is cultivated in rain fed condition. As a result, managing irrigation treatments in the major plots is exceedingly challenging. When supplemented irrigation was applied, treatment wise irrigation levels were maintained. Necessary irrigations were provided to the plots as and when required during the growing period of rice crop. Irrigation treatment of alternate wetting and drying was not properly maintained due to rainy season. The plots were infested with some common weeds, which were removed by uprooting them from the field three times during the period of the cropping season. There were no disease infestations in the area, but leaf rollers (Chaphalocrosis medinalis, Pyralidae, Lepidoptera) were seen and Malathion @ $1.12 \mathrm{~L} \mathrm{ha}^{-1}$ was used to monitor them. On November 26, the field was harvested at full maturity, when 80 90 percent of the grains had become straw colored. The crop was cut at ground level, and each plot's crop was packaged and taken 
to the threshing floor separately. Eight rice plant hills were chosen at random from the plants to be measured for yield contributing characters.

\section{Data collection and analysis}

Data were collected in the following variables, effective tiller/ hill, plant height $(\mathrm{cm})$, panicle length $(\mathrm{cm})$, number of unfilled and filled grain per panicle, weight of 1000 seeds (g), straw yield (ton/ ha), grain yield (ton/ ha). The statistical test ANOVA (Analysis of Variance) was done with the help of the SPSS (22.0) statistical data analysis software while the data mean separations were adjusted by the DMRT (Duncan's Multiple Range Test) [16].

\section{Chemical analysis of plant samples}

After threshing, grain and straw samples were obtained for N, P, $\mathrm{K}$, and $\mathrm{S}$ analysis. The plant samples were dried in a $70^{\circ} \mathrm{C}$ oven for 72 hours before being ground in a wiley-mill and passing through a 20-mesh sieve. The samples were held in a plastic vial for $\mathrm{N}, \mathrm{P}$, $\mathrm{K}$, and $\mathrm{S}$ analysis. The concentrations of $\mathrm{N}, \mathrm{P}, \mathrm{K}$, and $\mathrm{S}$ in grain and straw samples were determined. The nutrient contents of straw and grain samples were determined after chemical examination, and nutrient uptakes were calculated using the following formula:

Nutrient uptake $(\mathrm{kg} / \mathrm{plot})=\{$ Nutrient content $(\%) / 100 \times$ Yield $(\mathrm{kg} /$ plot)\}

\section{Results and Discussion}

\section{Effect of irrigation}

Effect of irrigation on yield contributing characters and yield of T-Aman

Insignificant variation was observed on the effective tillers/hill of rice when the field was irrigated with two different irrigations. Between these two irrigations, $\mathrm{I}_{1}$ (Continuous flooding) showed the highest number of effective tillers/hill (8.27) and $I_{2}$ (Alternate wetting and drying) irrigation showed lowest number of effective tillers/hill (8.20) presented in table 4. Similar trend of result was found in plant height, panicle length, 1000 grain weight, straw yield and grain yield. $\mathrm{I}_{1}$ (Continuous flooding) showed the highest plant height $\left(116.54 \mathrm{~cm}\right.$ ) and $\mathrm{I}_{2}$ (Alternate wetting and drying) irrigation showed lowest plant height $(116.38 \mathrm{~cm}) . \mathrm{I}_{2}$ (alternate wetting and drying) showed the highest panicle length $(24.91 \mathrm{~cm})$ and $\mathrm{I}_{1}$ (continuous flooding) irrigation showed lowest panicle length (24.04 cm). I (Continuous flooding)) showed the highest number of filled grain per panicle (88.91) and $\mathrm{I}_{2}$ (Alternate wetting and drying irrigation) showed lowest number of filled grain per panicle
(85.11). $\mathrm{I}_{2}$ (alternate wetting and drying) showed the highest 1000 grain wt. (20.92g) and $\mathrm{I}_{1}$ (continuous flooding) irrigation showed lowest 1000 grain wt. (20.81g). $\mathrm{I}_{2}$ (Alternate wetting and drying irrigation) showed the highest straw yield (4.71 kg/plot). (9.43 t/ ha) and $\mathrm{I}_{1}$ (Continuous flooding) showed lowest straw yield (4.68 $\mathrm{kg} / \mathrm{plot}$ ) (9.35 t/ha). $\mathrm{I}_{1}$ (Continuous flooding) showed the highest grain yield (2.36 kg/plot) and $\mathrm{I}_{2}$ (Alternate wetting and drying) irrigation showed lowest grain yield $(2.35 \mathrm{~kg} / \mathrm{plot})$. Numerically, the highest grain yield (4.72 t/ha) was found in $\mathrm{I}_{1}$ (Continuous flooding) and the lowest grain yield (4.70 t/ha) was recorded in $\mathrm{I}_{2}$ (Alternate wetting and drying) irrigation, respectively (Figure 1).

\begin{tabular}{|l|c|c|c|c|c|c|}
\hline $\begin{array}{l}\text { Treat- } \\
\text { ments }\end{array}$ & $\begin{array}{c}\text { No. of } \\
\text { effective } \\
\text { tillers/ } \\
\text { hill }\end{array}$ & $\begin{array}{c}\text { Plant } \\
\text { height } \\
\text { (cm) }\end{array}$ & $\begin{array}{c}\text { Pan- } \\
\text { icle } \\
\text { length } \\
\text { (cm) }\end{array}$ & $\begin{array}{c}\mathbf{1 0 0 0} \\
\text { grain } \\
\text { wt. } \\
\text { (g) }\end{array}$ & $\begin{array}{c}\text { Straw } \\
\text { yield/ } \\
\text { plot } \\
\text { (kg) }\end{array}$ & $\begin{array}{c}\text { Grain } \\
\text { yield/ } \\
\text { plot } \\
\text { (kg) }\end{array}$ \\
\hline $\mathrm{I}_{1}$ & 8.27 & 116.54 & 24.04 & 20.81 & 4.68 & 2.36 \\
\hline $\mathrm{I}_{2}$ & 8.20 & 116.38 & 24.91 & 20.92 & 4.71 & 2.35 \\
\hline $\mathrm{SE}( \pm)$ & $\mathrm{ns}$ & $\mathrm{ns}$ & $\mathrm{ns}$ & $\mathrm{ns}$ & $\mathrm{ns}$ & $\mathrm{ns}$ \\
\hline
\end{tabular}

Table 4: Effect of irrigation on yield contributing characters and yield of T-Aman

According to DMRT, figures with identical letter(s) do not differ significantly while figures with dissimilar letter(s) varied significantly.

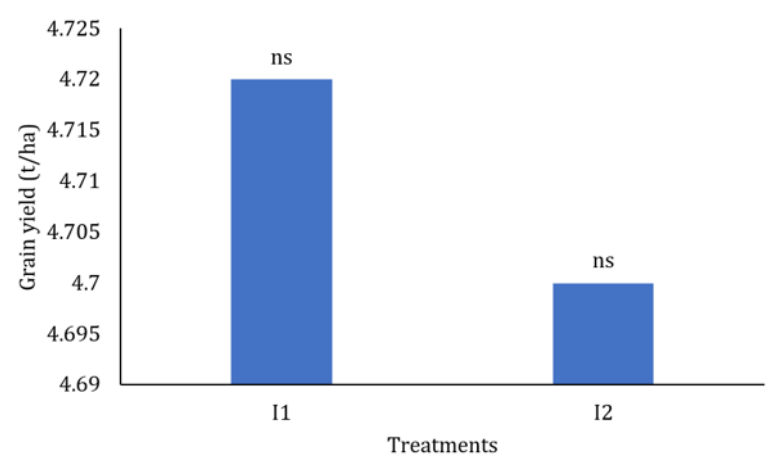

Figure 1: Effect of irrigation on grain yield (t/ha) on Transplanted-Aman rice.

Effect of irrigation on NPKS concentration in rice grain and straw

The effects of irrigation on NPKS concentration in grain and straw of rice are presented in table 5. Insignificant variation was observed on NPKS concentration in rice grain when the field was 
irrigated with two different irrigations. The highest $\mathrm{N}$ concentration in grain $(1.224 \%)$ was observed in $\mathrm{I}_{2}$ (Alternate wetting and drying) irrigation and the lowest $\mathrm{N}$ concentration in grain (1.142\%) was taken from $\mathrm{I}_{1}$ (Continuous flooding). $\mathrm{I}_{1}$ (Continuous flooding) showed the highest $(0.238 \%) \mathrm{P}$ concentration in grain and $\mathrm{I}_{2}(\mathrm{Al}-$ ternate wetting and drying) irrigation showed the lowest $(0.217 \%)$ $\mathrm{P}$ concentration in grain. $\mathrm{I}_{1}$ (continuous flooding) showed the highest $\mathrm{K}$ concentration $(0.266 \%)$ in grain and $\mathrm{I}_{2}$ (alternate wetting and drying) irrigation showed the lowest K concentration $(0.247 \%)$ in grain. $I_{1}$ (Continuous flooding) showed the lowest $\mathrm{S}$ concentration in grain $(0.163 \%)$ and $I_{2}$ (Alternate wetting and drying) irrigation showed the highest $\mathrm{S}$ concentration in grain $(0.176 \%)$. Similar trend of result was found in case of NPKS concentration in rice straw. $\mathrm{I}_{1}$ (Continuous flooding) showed the lowest $\mathrm{N}$ concentration in straw $(0.54 \%)$ and $I_{2}$ (Alternate wetting and drying) irrigation showed the highest $\mathrm{N}$ concentration in straw $(0.60 \%)$. Between these two irrigations, $\mathrm{I}_{1}$ (Continuous flooding) showed the P concentration in straw $(0.138 \%)$ and $I_{2}$ (Alternate wetting and drying) irrigation showed the P concentration in straw (0.122\%). $\mathrm{I}_{1}$ (Continuous flooding) showed the lowest $\mathrm{K}$ concentration in straw $\left(1.354 \%\right.$ ) and $\mathrm{I}_{2}$ (Alternate wetting and drying) irrigation showed the highest $\mathrm{K}$ concentration in straw (1.442\%). I (Continuous flooding) showed the $S$ concentration in straw $(0.110 \%)$ and $\mathrm{I}_{2}(\mathrm{Al}-$ ternate wetting and drying) irrigation showed the $\mathrm{S}$ concentration in straw $(0.120 \%)$ which were almost similar.

\begin{tabular}{|l|c|c|c|c|c|c|c|c|}
\hline \multirow{2}{*}{ Treatments } & \multicolumn{4}{|c|}{ Concentration (\%) in grain } & \multicolumn{4}{c|}{ Concentration (\%) in straw } \\
\cline { 2 - 9 } & $\mathbf{N}$ & $\mathbf{P}$ & $\mathbf{K}$ & $\mathbf{S}$ & $\mathbf{N}$ & $\mathbf{P}$ & $\mathbf{K}$ & $\mathbf{S}$ \\
\hline $\mathrm{I}_{1}$ & 1.142 & 0.238 & 0.266 & 0.163 & $0.544 \mathrm{~b}$ & 0.138 & 1.354 & 0.110 \\
\hline $\mathrm{I}_{2}$ & 1.224 & 0.217 & 0.247 & 0.176 & $0.600 \mathrm{a}$ & 0.122 & 1.442 & 0.120 \\
\hline $\mathrm{SE}( \pm)$ & $\mathrm{ns}$ & $\mathrm{ns}$ & $\mathrm{ns}$ & $\mathrm{ns}$ & 0.0093 & $\mathrm{~ns}$ & $\mathrm{~ns}$ & $\mathrm{~ns}$ \\
\hline
\end{tabular}

Table 5: Effect of irrigation on NPKS concentration in T-Aman rice grain and straw.

According to DMRT, figures with identical letter(s) do not differ significantly while figures with dissimilar letter(s) varied significantly.

Effect of irrigation on NPKS uptake by T-Aman rice grain and straw

The effects of irrigation on NPKS uptake by grain and straw of rice are presented in table 6. Insignificant variation was observed on $\mathrm{N}$ uptake by grain of rice when the field was irrigated with two different irrigations. Between these two irrigations, $\mathrm{I}_{1}$ (Continuous flooding) showed the grain $\mathrm{N}$ uptake of $0.027 \mathrm{~kg} / \mathrm{plot}$ and $\mathrm{I}_{2}$ (Alternate wetting and drying) irrigation showed the grain $\mathrm{N}$ uptake of $0.028 \mathrm{~kg} /$ plot which were almost similar. $\mathrm{I}_{1}$ (Continuous flooding) showed the $\mathrm{P}$ uptake by grain $(0.005 \mathrm{~kg} / \mathrm{plot})$ and $\mathrm{I}_{2}$ (Alternate wetting and drying) irrigation showed the same $\mathrm{P}$ uptake by T-Aman rice grain $(0.005 \mathrm{~kg} / \mathrm{plot})$. Between these two irrigations, $\mathrm{I}_{1}$ (Continuous flooding) showed the K uptake of grain $(0.015 \mathrm{~kg} /$ plot) and $\mathrm{I}_{2}$ (Alternate wetting and drying) irrigation also showed the same amount of K uptake of grain $(0.015 \mathrm{~kg} / \mathrm{plot}) . \mathrm{I}_{1}$ (Continuous flooding) showed the $\mathrm{S}$ uptake of grain $(0.004 \mathrm{~kg} / \mathrm{plot})$ and $\mathrm{I}_{2}$ (Alternate wetting and drying) irrigation showed the same amount of S uptake of T-Aman rice grain $(0.004 \mathrm{~kg} / \mathrm{plot})$. On the other hand, in case of straw, $\mathrm{I}_{1}$ (Continuous flooding) showed the lowest $\mathrm{N}$ uptake of straw $(0.025 \mathrm{~kg} / \mathrm{plot})$ and $\mathrm{I}_{2}$ (Alternate wetting and drying) irrigation showed the highest $\mathrm{N}$ uptake of straw $(0.029 \mathrm{~kg} / \mathrm{plot})$. $\mathrm{I}_{1}$ (Continuous flooding) showed the P uptake of straw $(0.006 \mathrm{~kg} /$ plot) and $\mathrm{I}_{2}$ (Alternate wetting and drying) irrigation showed the same P uptake of straw $(0.006 \mathrm{~kg} / \mathrm{plot}) . \mathrm{I}_{1}$ (Continuous flooding) showed the lowest $S$ uptake in straw $(0.005 \mathrm{~kg} / \mathrm{plot})$ and $\mathrm{I}_{2}$ (Alternate wetting and drying) irrigation showed the highest $\mathrm{S}$ uptake in straw $(0.006 \mathrm{~kg} / \mathrm{plot})$.

\begin{tabular}{|l|c|c|c|c|c|c|c|c|}
\hline \multirow{2}{*}{ Treatments } & \multicolumn{4}{|c|}{ Uptake by grain (kg/plot) } & \multicolumn{4}{c|}{ Uptake by straw (kg/plot) } \\
\cline { 2 - 9 } & $\mathbf{N}$ & $\mathbf{P}$ & $\mathbf{K}$ & $\mathbf{S}$ & $\mathbf{N}$ & $\mathbf{P}$ & $\mathbf{K}$ & $\mathbf{S}$ \\
\hline $\mathrm{I}_{1}$ & 0.027 & 0.005 & 0.15 & 0.004 & 0.025 & 0.006 & 0.063 & 0.005 \\
\hline $\mathrm{I}_{2}$ & 0.028 & 0.005 & 0.15 & 0.004 & 0.029 & 0.006 & 0.094 & 0.006 \\
\hline $\mathrm{SE}( \pm)$ & $\mathrm{ns}$ & $\mathrm{ns}$ & $\mathrm{ns}$ & $\mathrm{ns}$ & $\mathrm{ns}$ & $\mathrm{ns}$ & $\mathrm{ns}$ & $\mathrm{ns}$ \\
\hline
\end{tabular}

Table 6: Effect of irrigation on NPKS uptake by T-Aman rice grain and straw.

According to DMRT, figures with identical letter(s) do not differ significantly while figures with dissimilar letter(s) varied significantly. 
Effects of different doses of fertilizer and manure

Effects of different doses of fertilizer and manure on yield contributing characters and yield of T-Aman

Different doses of fertilizers showed significant variations in yield contributing characters and yield of T-Aman rice (Table 7). Among the different doses of fertilizers, $\mathrm{T}_{2}:(50 \% \mathrm{NPKSZn}+5$ ton cowdung/ha) showed the highest number of effective tillers/hill (9.13) which was followed (8.99) by $\mathrm{T}_{7}$ : $(70 \%$ NPKSZn +2.1 poultry manure/ha) treatment. On the contrary, the lowest number of effective tillers/hill (7.58) was observed with $\mathrm{T}_{0}$ where no fertilizer was applied. Nayak., et al. [17] reported a significant increase in effective tillers/hill due to application of chemical fertilizer with organic manure. Similar results also found by Rahman., et al. [18] and Reddy., et al. [19]. Rice plants showed significant variation in respect of plant height when fertilizers of different doses were applied. Among the different fertilizer doses, $\mathrm{T}_{3}(70 \% \mathrm{NPKSZn}+3$ ton cowdung/ha) showed the highest plant height $(119.79 \mathrm{~cm})$, which was closely followed by $(119.49 \mathrm{~cm}) \mathrm{T}_{7}(: 70 \% \mathrm{NPKSZn}+2.1$ poultry manure/ha). On the other hand, lowest plant height (105.43 $\mathrm{cm}$ ) was observed in the $\mathrm{T}_{0}$ treatment where no fertilizer was applied. Almost similar plant heights were obtained where $100 \%$ recommended dose of fertilizer, 50\% organic plus inorganic and 30\% organic plus $70 \%$ inorganic fertilizer were applied. Plant height was significantly influenced by the application of organic manure and chemical fertilizers reported by Nayak., et al. [17]. Similar results also reported by Aga., et al. [20]. $\mathrm{T}_{5}$ (70\% chemical fertilizer +5 ton cowdung) showed the highest panicle length $(27.96 \mathrm{~cm})$,on the other hand lowest panicle length $(23.05 \mathrm{~cm})$ was observed in the $\mathrm{T}_{0}$ treatment where no fertilizer was applied. Rahman et al. [18] noted a significant increase in panicle length due to the application of organic manure and chemical fertilizers. Babu., et al. [21] and Reddy., et al. [22] also reported similar results. Higher number of filled grains/panicle was found in organic plus inorganic treatments compared to inorganic fertilizer alone. The highest number of filled grain per panicle (97.21) was recorded in $\mathrm{T}_{3}$ (70\% NPKSZn +3 ton cowdung $\mathrm{t} / \mathrm{ha}$ ) treatment which was statistically similar to $\mathrm{T}_{6}(50 \% \mathrm{NPKSZn}+3.5$ ton poultry manure $/ \mathrm{ha}), \mathrm{T}_{7}(70 \% \mathrm{NPKSZn}+$ 2.1 ton poultry manure/ha), $\mathrm{T}_{4}(50 \% \mathrm{NPKSZn}+5$ ton compost/ha) treatments. The lowest number of filled grain per panicle (71.86) was recorded in $\mathrm{T}_{0}$ (control treatment). Among the different fertilizer doses, $\mathrm{T}_{4}(50 \%$ NPKSZn +5 ton compost/ha) showed the highest 1000 grain wt. (21.67 g) which was statistically comparable to other treatments of $\mathrm{T}_{3}\left(70 \%\right.$ NPKSZn +3 ton cowdung/ha), $\mathrm{T}_{6}$
(50\% NPKSZn + 3.5 ton poultry manure/ha) and $\mathrm{T}_{7}$ (70\% NPKSZn +2.1 ton poultry manure/ha) treatments. On the other hand, the lowest 1000 grain wt. (19.583 g) was observed in the $\mathrm{T}_{0}$ treatment where no fertilizer was applied. Significant variation was observed on the straw yield/plot of rice when different doses of fertilizer were applied. The highest yield of straw/plot (5.05 kg/plot) (10 $\mathrm{t} / \mathrm{ha}$ ) was recorded in $\mathrm{T}_{1}\left(100 \% \mathrm{~N}_{100} \mathrm{P}_{15} \mathrm{~K}_{45} \mathrm{~S}_{20} \mathrm{Zn}_{2}\right)$ (Recommended dose of fertilizer) treatment which was statistically similar to $\mathrm{T}_{2}$ (50\% NPKSZn + 5 ton cowdung/ha), $\mathrm{T}_{3}(70 \% \mathrm{NPKSZn}+3$ ton cowdung/ha) and $\mathrm{T}_{4}(50 \%$ NPKSZn +5 ton compost/ha) treatment, The lowest straw yield/plot (3.70 kg/plot) (7.40 t/ha) was recorded in the $\mathrm{T}_{0}$ treatment where no fertilizer was applied. The straw yield increase varied from $11.4 \%$ to $38.3 \%$ and the highest level of straw yield increase was found in the $\mathrm{T}_{1}\left(100 \% \mathrm{~N}_{100} \mathrm{P}_{15} \mathrm{~K}_{45} \mathrm{~S}_{20} \mathrm{Zn}_{2}\right)$ treatment where highest level of chemical fertilizer was used. The application of fertilizers and manure had a positive effect on the grain yield of T-Aman rice. The yield increase varied from $11.4 \%$ to $38.3 \%$ and lowest yield increase was observed in $\mathrm{T}_{1}$ (recommended chemical fertilizer) treatment. The higher levels of $\%$ grain yield increase was observed in the integrated use of fertilizer and manure compared to chemical fertilizer alone. Among the different doses of fertilizers, $\mathrm{T}_{7}(70 \%$ NPKSZn +2.1 ton poultry manure/ ha) showed the highest grain yield/plot (2.56 kg/plot) which was statistically similar with all other treatments except control treatment. On the contrary, the lowest grain yield/plot (1.85 kg/plot) was observed with $\mathrm{T}_{0}$ where no fertilizer was applied. The highest grain yield (5.12 t/ha) was recorded in $\mathrm{T}_{7}(70 \%$ NPKSZn +2.1 ton poultry manure/ha) and the lowest grain yield (3.70 t/ha) was observed in control (Figure 2). The higher grain yield was found in the treatments where organic plus inorganic fertilizers were used. The yield decreased in order of $\mathrm{T}_{7}(70 \% \mathrm{NPKSZn}+2.1$ ton poultry manure $/$ ha $)>\mathrm{T}_{6}(50 \%$ NPKSZn +3.5 ton poultry manure $/$ ha $)>\mathrm{T}_{3}$ (70\% NPKSZn + 3 ton cowdung/ha). Rahman et al. [18] reported the grain yield was significantly increased due to application of organic manure and chemical fertilizers. It was found that the highest grain, straw, and biological yield were obtained from the combination of vermicompost with NPKS fertilizers [23]. This was also in agreement with the findings of Miah., et al. [24] and Miah., et al. [25]. It is evident that organic manure, when used in accordance with inorganic fertilizers, stimulates plant vegetative growth and, as a result, improves rice straw yield. In china, the use of chemical fertilizer did not indicate very capable results as replace by green manure for rice cultivation [26]. 


\begin{tabular}{|l|c|c|c|c|c|c|}
\hline Treatments & $\begin{array}{c}\text { No. of effective } \\
\text { tillers/hill }\end{array}$ & $\begin{array}{c}\text { Plant } \\
\text { height (cm) }\end{array}$ & $\begin{array}{c}\text { Panicle } \\
\text { length } \mathbf{( c m} \text { ) }\end{array}$ & $\begin{array}{c}\text { 1000 grain } \\
\text { wt. (g) }\end{array}$ & $\begin{array}{c}\text { Straw yield } \\
\text { (kg/plot) }\end{array}$ & $\begin{array}{c}\text { Grain yield } \\
\text { (kg/plot) }\end{array}$ \\
\hline $\mathrm{T}_{0}$ & $7.58 \mathrm{~b}$ & $105.43 \mathrm{~b}$ & 23.05 & $19.58 \mathrm{c}$ & $3.70 \mathrm{c}$ & $1.85 \mathrm{~b}$ \\
\hline $\mathrm{T}_{1}$ & $8.00 \mathrm{ab}$ & $117.15 \mathrm{a}$ & 24.96 & $20.17 \mathrm{bc}$ & $5.05 \mathrm{a}$ & $2.06 \mathrm{ab}$ \\
\hline $\mathrm{T}_{2}$ & $9.13 \mathrm{a}$ & $118.17 \mathrm{a}$ & 23.47 & $21.17 \mathrm{ab}$ & $4.93 \mathrm{ab}$ & $2.45 \mathrm{a}$ \\
\hline $\mathrm{T}_{3}$ & $8.08 \mathrm{ab}$ & $119.79 \mathrm{a}$ & 23.86 & $21.08 \mathrm{ab}$ & $4.77 \mathrm{ab}$ & $2.55 \mathrm{a}$ \\
\hline $\mathrm{T}_{4}$ & $8.46 \mathrm{ab}$ & $117.67 \mathrm{a}$ & 24.30 & $21.67 \mathrm{a}$ & $4.70 \mathrm{ab}$ & $2.43 \mathrm{a}$ \\
\hline $\mathrm{T}_{5}$ & $7.75 \mathrm{ab}$ & $116.75 \mathrm{a}$ & 27.96 & $20.67 \mathrm{abc}$ & $4.90 \mathrm{ab}$ & $2.39 \mathrm{a}$ \\
\hline $\mathrm{T}_{6}$ & $7.88 \mathrm{ab}$ & $117.27 \mathrm{a}$ & 24.03 & $21.25 \mathrm{ab}$ & $4.53 \mathrm{~b}$ & $2.55 \mathrm{a}$ \\
\hline $\mathrm{T}_{7}$ & $8.99 \mathrm{a}$ & $119.45 \mathrm{a}$ & 24.18 & $21.33 \mathrm{ab}$ & $4.97 \mathrm{ab}$ & $2.56 \mathrm{a}$ \\
\hline $\mathrm{SE}( \pm)$ & 0.38 & 2.113 & $n s$ & 0.388 & 0.123 & 0.142 \\
\hline
\end{tabular}

Table 7: Effect of different doses of fertilizer and manure on yield contributing characters and yield of T-Aman.

According to DMRT, figures with identical letter(s) do not differ significantly while figures with dissimilar letter(s) varied significantly.

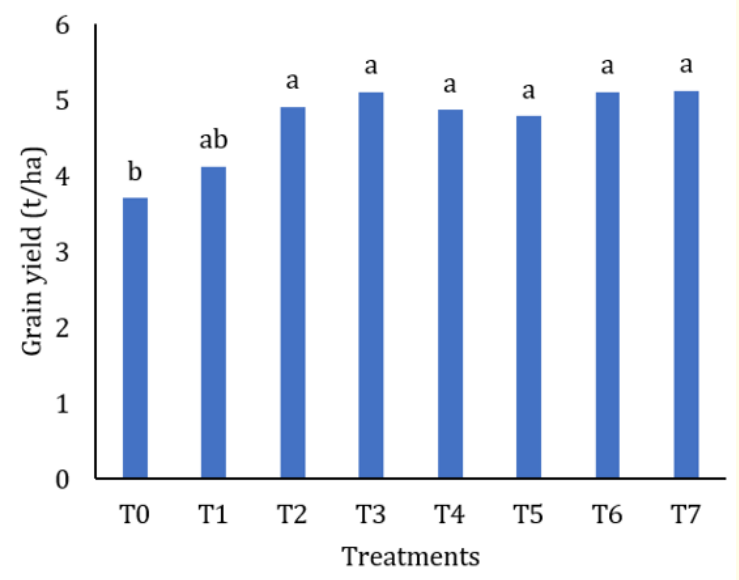

Figure 2: Effect of different doses of fertilizer and manure on grain yield ( $\mathrm{t} / \mathrm{ha}$ ) on Transplanted-Aman rice.

Effect of different doses of fertilizer and manure on NPKS concentration of rice grain and straw

The concentrations of NPKS in rice grain and straw showed statistically significant variation due to the application of different doses of fertilizers are presented in Table 8. The highest $\mathrm{N}$ concentration in grain $(1.295 \%)$ was recorded from $\mathrm{T}_{6}(50 \%$ NPKSZn + 3.5 ton poultry manure/ha) compared to (1.225\%) by $\mathrm{T}_{1}$ as $100 \%$ NPKSZn. On the other hand, the lowest $\mathrm{N}$ concentration in grain $(1.073 \%)$ was found from $\mathrm{T}_{0}$ as control treatment which was closely followed (1.085\%) by $\mathrm{T}_{4}$ as $50 \% \mathrm{NPKSZn}+5$ ton compost/ha. A significant increase in $\mathrm{N}$ content in rice grain due to the application of organic manure and fertilizers have been reported by investigators $[27,28]$. The highest $\mathrm{P}$ concentration in grain $(0.267 \%)$ was recorded from $\mathrm{T}_{3}(70 \%$ NPKSZn +3 ton cowdung/ha). On the other hand, the lowest $\mathrm{P}$ concentration in grain $(0.175 \%)$ was found from $\mathrm{T}_{0}$ as control treatment. The highest $\mathrm{K}$ concentration in grain $(0.282 \%)$ was recorded from $\mathrm{T}_{2}(50 \% \mathrm{NPKSZn}+5$ ton cowdung), $\mathrm{T}_{4}\left(50 \%\right.$ NPKSZn +5 ton compost/ha), $\mathrm{T}_{6}(50 \%$ NPKSZn +3.5 ton poultry manure/ha) and in $\mathrm{T}_{7}(70 \%$ NPKSZn +2.1 ton poultry manure/ha) treatments. The combined application of fertilizer and manure increased the $\mathrm{K}$ accumulation in rice grain. On the other hand, the lowest $\mathrm{K}$ concentration in grain $(0.207 \%)$ was found from $\mathrm{T}_{0}$ as control treatment. Singh., et al. [29] revealed that Potassium content in grains were increased due to combined application of organic manure and chemical fertilizers. The highest $\mathrm{S}$ concentration in grain $(0.204 \%)$ was recorded from $\mathrm{T}_{7}(70 \% \mathrm{NPKSZn}+2.1$ ton poultry manure/ha). which was closely followed by $(0.196 \%)$ at $\mathrm{T}_{1}(100 \%$ NPKSZn). On the other hand, the lowest $\mathrm{S}$ concentration in grain $(0.096 \%)$ was found from $\mathrm{T}_{0}$ as control treatment. The NKPS concentration of T-Aman rice straw significantly increased due to the application of fertilizer and manure. The higher levels of $\mathrm{N}$ concentrations were found in the treatments where fertilizer and manure were combinedly applied. The highest $\mathrm{N}$ concentration in straw $(0.630 \%)$ was recorded from $\mathrm{T}_{1}(100 \%$ NPKSZn) which was statistically same as $(0.630 \%)$ by $\mathrm{T}_{2}(50 \%$ NPKSZn + 5 ton cowdung/ha), $\mathrm{T}_{6}(50 \%$ NPKSZn +3.5 ton poultry manure/ ha), $\mathrm{T}_{7}\left(70 \%\right.$ NPKSZn +2.1 ton poultry manure/ha) and $\mathrm{T}_{3}(70 \%$ NPKSZn +3 ton cowdung/ha) treatments. On the other hand, the lowest $\mathrm{N}$ concentration in straw $(0.477 \%)$ was found from $\mathrm{T}_{0}$ as 
control treatment. The highest P concentration in straw $(0.140 \%)$ was recorded from $\mathrm{T}_{2}(50 \%$ NPKSZn +5 ton cowdung/ha). On the other hand, the lowest $\mathrm{P}$ concentration in straw $(0.113 \%)$ was found from $\mathrm{T}_{0}$ as control treatment. The highest $\mathrm{K}$ concentration in straw $(1.667 \%)$ was recorded from $\mathrm{T}_{7}(70 \%$ NPKSZn +2.1 ton poultry manure/ha) which was statistically similar to $(1.506 \%)$ at $\mathrm{T}_{4}$ as $50 \%$ NPKSZn +5 ton compost/ha. Higher level of $\mathrm{K}$ was accumulated in combined application of organic plus inorganic fertilizer. Among the organic plus inorganic treatments, higher level of $\mathrm{K}$ was accumulated where compost and poultry manure were used in combination with inorganic fertilizer. On the other hand, the lowest $\mathrm{K}$ concentration in straw $(1.282 \%)$ was found from $\mathrm{T}_{0}$ as control treatment. The highest S concentration in straw $(0.163 \%)$ was recorded from $\mathrm{T}_{7}(70 \% \mathrm{NPKSZn}+2.1$ ton poultry manure/ha) which was statistically identical $(0.138 \%)$ with $\mathrm{T}_{5}$ as $70 \%$ NPKSZn + 3 ton compost/ha. On the other hand, the lowest $\mathrm{S}$ concentration in straw $(0.066 \%)$ was found from $\mathrm{T}_{0}$ as control treatment. Organic farming had slightly higher total organic $\mathrm{C}$ and $\mathrm{N}$ contents, as well as microbial biomass, than traditional farming [30]. Maharjan., et al. [30] mentioned land-management significantly affected the top soil properties that may rise the soil nutrients.

\begin{tabular}{|l|c|c|c|c|c|c|c|c|}
\hline \multirow{2}{*}{ Treatments } & \multicolumn{4}{|c|}{ Concentration (\%) in grain } & \multicolumn{4}{c|}{ Concentration (\%) in straw } \\
\cline { 2 - 9 } & $\mathbf{N}$ & $\mathbf{P}$ & $\mathbf{K}$ & $\mathbf{S}$ & $\mathbf{N}$ & $\mathbf{P}$ & $\mathbf{K}$ & $\mathbf{S}$ \\
\hline $\mathrm{T}_{0}$ & $1.073 \mathrm{c}$ & $0.175 \mathrm{f}$ & $0.207 \mathrm{~b}$ & $0.096 \mathrm{~b}$ & $0.477 \mathrm{c}$ & $0.113 \mathrm{e}$ & $1.282 \mathrm{c}$ & $0.066 \mathrm{~d}$ \\
\hline $\mathrm{T}_{1}$ & $1.225 \mathrm{a}$ & $0.240 \mathrm{~b}$ & $0.250 \mathrm{ab}$ & $0.196 \mathrm{a}$ & $0.630 \mathrm{a}$ & $0.129 \mathrm{c}$ & $1.346 \mathrm{bc}$ & $0.096 \mathrm{bcd}$ \\
\hline $\mathrm{T}_{2}$ & $1.190 \mathrm{ab}$ & $0.230 \mathrm{c}$ & $0.282 \mathrm{a}$ & $0.167 \mathrm{a}$ & $0.630 \mathrm{a}$ & $0.140 \mathrm{a}$ & $1.378 \mathrm{bc}$ & $0.133 \mathrm{abc}$ \\
\hline $\mathrm{T}_{3}$ & $1.190 \mathrm{ab}$ & $0.265 \mathrm{a}$ & $0.250 \mathrm{ab}$ & $0.171 \mathrm{a}$ & $0.560 \mathrm{abc}$ & $0.136 \mathrm{~b}$ & $1.314 \mathrm{c}$ & $0.128 \mathrm{abc}$ \\
\hline $\mathrm{T}_{4}$ & $1.085 \mathrm{bc}$ & $0.232 \mathrm{c}$ & $0.282 \mathrm{a}$ & $0.167 \mathrm{a}$ & $0.525 \mathrm{bc}$ & $0.132 \mathrm{bc}$ & $1.506 \mathrm{ab}$ & $0.090 \mathrm{~cd}$ \\
\hline $\mathrm{T}_{5}$ & $1.190 \mathrm{ab}$ & $0.225 \mathrm{~d}$ & $0.218 \mathrm{~b}$ & $0.181 \mathrm{a}$ & $0.560 \mathrm{abc}$ & $0.134 \mathrm{~b}$ & $1.314 \mathrm{c}$ & $0.138 \mathrm{ab}$ \\
\hline $\mathrm{T}_{6}$ & $1.295 \mathrm{a}$ & $0.240 \mathrm{~b}$ & $0.282 \mathrm{a}$ & $0.173 \mathrm{a}$ & $0.595 \mathrm{ab}$ & $0.124 \mathrm{~d}$ & $1.378 \mathrm{bc}$ & $0.106 \mathrm{bcd}$ \\
\hline $\mathrm{T}_{7}$ & $1.213 \mathrm{a}$ & $0.217 \mathrm{e}$ & $0.282 \mathrm{a}$ & $0.204 \mathrm{a}$ & $0.598 \mathrm{ab}$ & $0.132 \mathrm{bc}$ & $1.667 \mathrm{a}$ & $0.163 \mathrm{a}$ \\
\hline $\mathrm{SE}( \pm)$ & 0.0321 & 0.0070 & 0.0127 & 0.0172 & 0.028 & 0.004 & 0.052 & 0.012 \\
\hline
\end{tabular}

Table 8: Effect of different doses of fertilizer and manure on NPKS concentration in T-Aman rice grain and straw.

According to DMRT, figures with identical letter(s) do not differ significantly while figures with dissimilar letter(s) varied significantly.

Effect of different doses of fertilizer and manure on NPKS uptake by rice grain and straw

NPKS uptake by rice grain and straw showed statistically significant variation due to the application of different doses of fertilizers is presented in table 9 . The highest $\mathrm{N}$ uptake by grain $(0.033 \mathrm{~kg} /$ plot) was recorded from $\mathrm{T}_{6}(50 \%$ NPKSZn +3.5 ton poultry manure/ha) which was closely followed $(0.030 \mathrm{~kg} / \mathrm{plot})$ by $\mathrm{T}_{3}$ as $70 \%$ NPKSZn +3 ton cowdung/ha. On the other hand, the lowest $\mathrm{N}$ uptake by grain $(0.021 \mathrm{~kg} / \mathrm{plot})$ was found from $\mathrm{T}_{0}$ as control treatment. Sengar., et al. [31] reported that the $\mathrm{N}$ uptake by rice grain and straw increased significantly with the combined application of organic manure and chemical fertilizers. Rahman [32]; Duhan and Singh [33] also reported similar results. The highest $\mathrm{P}$ uptake by grain $(0.007 \mathrm{~kg} /$ plot $)$ was recorded from $\mathrm{T}_{3}(70 \%$ NPKSZn +3 ton cowdung/ha) which was closely $(0.006 \mathrm{~kg} / \mathrm{plot})$ followed by
$\mathrm{T}_{2}$ as $50 \%$ NPKSZn +5 ton cowdung/ha and $\mathrm{T}_{6}(50 \% \mathrm{NPKSZn}+3.5$ ton poultry manure/ha). On the other hand, the lowest $\mathrm{P}$ uptake by grain $(0.003 \mathrm{~kg} / \mathrm{plot})$ was found from $\mathrm{T}_{0}$ as control treatment. The highest $\mathrm{K}$ uptake by grain $(0.016 \mathrm{~kg} / \mathrm{plot})$ was recorded from $\mathrm{T}_{2}\left(50 \%\right.$ NPKSZn + 5 ton cowdung/ha) and $\mathrm{T}_{6}$ (50\% NPKSZn + 3.5 ton poultry manure/ha). On the other hand, the lowest $\mathrm{K}$ uptake by grain $(0.012 \mathrm{~kg} / \mathrm{plot})$ was found from $\mathrm{T}_{0}$ as control treatment. The highest $\mathrm{S}$ uptake by grain $(0.005 \mathrm{~kg} / \mathrm{plot})$ was recorded from $\mathrm{T}_{6}\left(50 \%\right.$ NPKSZn +3.5 ton poultry manure/ha) and $\mathrm{T}_{7}(70 \% \mathrm{NPK}-$ $\mathrm{SZn}+2.1$ ton poultry manure/ha). On the other hand, the lowest $\mathrm{S}$ uptake by grain $(0.002 \mathrm{~kg} / \mathrm{plot})$ was found from $\mathrm{T}_{0}$ as control treatment. The highest $\mathrm{N}$ uptake by grain $(0.033 \mathrm{~kg} / \mathrm{plot})$ was recorded from $\mathrm{T}_{6}(50 \%$ NPKSZn +3.5 ton poultry manure/ha) which was closely followed $(0.030 \mathrm{~kg} / \mathrm{plot})$ by $\mathrm{T}_{3}$ as $70 \% \mathrm{NPKSZn}+3$ ton cowdung/ha. On the other hand, the lowest $\mathrm{N}$ uptake by grain $(0.021$ 
$\mathrm{kg} / \mathrm{plot}$ ) was found from $\mathrm{T}_{0}$ as control treatment. The highest $\mathrm{P}$ uptake by straw $(0.007 \mathrm{~kg} / \mathrm{plot})$ was recorded from $\mathrm{T}_{5}(70 \%$ NPKSZn + 3 ton compost $/ \mathrm{ha})$ which was statistically identical $(0.007 \mathrm{~kg} /$ plot) with $\mathrm{T}_{2}$ as $50 \%$ NPKSZn +5 ton cowdung/ha. On the other hand, the lowest $\mathrm{P}$ uptake by straw $(0.004 \mathrm{~kg} / \mathrm{plot})$ was found from $\mathrm{T}_{0}$ as control treatment. The highest $\mathrm{K}$ uptake by straw $(0.174 \mathrm{~kg} /$ plot) was recorded from $\mathrm{T}_{1}(100 \%$ NPKSZn). On the other hand, the lowest $\mathrm{K}$ uptake by straw $(0.047 \mathrm{~kg} / \mathrm{plot})$ was found from $\mathrm{T}_{0}$ as control treatment. The highest $\mathrm{S}$ uptake by straw $(0.008 \mathrm{~kg} / \mathrm{plot})$ was recorded from $\mathrm{T}_{7}(70 \% \mathrm{NPKSZn}+2.1$ ton poultry manure/ha). On the other hand, the lowest $\mathrm{S}$ uptake by straw $(0.002 \mathrm{~kg} / \mathrm{plot})$ was found from $\mathrm{T}_{0}$ as control treatment.

\begin{tabular}{|l|c|c|c|c|c|c|c|c|}
\hline \multirow{2}{*}{ Treatments } & \multicolumn{3}{|c|}{ Uptake by grain (kg/plot) } & \multicolumn{3}{c|}{ Uptake by straw (kg/plot) } \\
\cline { 2 - 9 } & $\mathbf{N}$ & $\mathbf{P}$ & $\mathbf{K}$ & $\mathbf{S}$ & $\mathbf{N}$ & $\mathbf{P}$ & $\mathbf{K}$ & $\mathbf{S}$ \\
\hline $\mathrm{T}_{0}$ & $0.021 \mathrm{c}$ & $0.003 \mathrm{c}$ & 0.012 & 0.002 & $0.022 \mathrm{e}$ & $0.004 \mathrm{~b}$ & 0.047 & 0.002 \\
\hline $\mathrm{T}_{1}$ & $0.026 \mathrm{~b}$ & $0.005 \mathrm{ab}$ & 0.015 & 0.004 & $0.030 \mathrm{~b}$ & $0.006 \mathrm{a}$ & 0.174 & 0.005 \\
\hline $\mathrm{T}_{2}$ & $0.029 \mathrm{ab}$ & $0.006 \mathrm{ab}$ & 0.016 & 0.004 & $0.031 \mathrm{a}$ & $0.007 \mathrm{a}$ & 0.068 & 0.006 \\
\hline $\mathrm{T}_{3}$ & $0.030 \mathrm{ab}$ & $0.007 \mathrm{a}$ & 0.015 & 0.004 & $0.027 \mathrm{c}$ & $0.006 \mathrm{a}$ & 0.062 & 0.006 \\
\hline $\mathrm{T}_{4}$ & $0.026 \mathrm{~b}$ & $0.005 \mathrm{ab}$ & 0.015 & 0.004 & $0.025 \mathrm{~d}$ & $0.006 \mathrm{a}$ & 0.071 & 0.004 \\
\hline $\mathrm{T}_{5}$ & $0.029 \mathrm{ab}$ & $0.005 \mathrm{ab}$ & 0.015 & 0.004 & $0.027 \mathrm{c}$ & $0.007 \mathrm{a}$ & 0.064 & 0.007 \\
\hline $\mathrm{T}_{6}$ & & & & & & & & \\
\hline $\mathrm{T}_{7}$ & $0.033 \mathrm{a}$ & $0.006 \mathrm{ab}$ & 0.016 & 0.005 & $0.027 \mathrm{c}$ & $0.006 \mathrm{a}$ & 0.062 & 0.005 \\
\hline $\mathrm{SE}( \pm)$ & $0.028 \mathrm{~b}$ & $0.005 \mathrm{~b}$ & 0.015 & 0.005 & $0.027 \mathrm{c}$ & $0.006 \mathrm{a}$ & 0.083 & 0.008 \\
\hline & & & & & & & & \\
\hline
\end{tabular}

Table 9: Effect of different doses of fertilizer and manure on NPKS uptake by T-Aman rice grain and straw

According to DMRT, figures with identical letter(s) do not differ significantly while figures with dissimilar letter(s) varied significantly.

\section{Combined effects of irrigation with fertilizer and manure}

Combined effects of irrigation with fertilizer and manure on yield contributing characters and yield of T-Aman

The combined effect of irrigation with different doses of fertilizer and manure on the number of effective tillers/hill of rice was insignificant (Table 10). The highest number of effective tillers/hill of rice (9.50) was recorded in $\mathrm{I}_{1} \mathrm{~T}_{2}$ with treatment combination and the lowest number of effective tillers/hill (7.25) was found in $\mathrm{I}_{2} \mathrm{~T}_{0}$. The highest plant height $(121.24 \mathrm{~cm})$ was recorded in $\mathrm{I}_{1} \mathrm{~T}_{1}$ treatment combination and the lowest plant height $(103.96 \mathrm{~cm})$ was observed in the treatment combination of $\mathrm{I}_{2} \mathrm{~T}_{0}$. Significantly, the highest panicle length $(32.48 \mathrm{~cm})$ was recorded in $\mathrm{I}_{2} \mathrm{~T}_{5}$ treatment combination whereas the lowest panicle length $(23.01 \mathrm{~cm})$ was observed in $\mathrm{I}_{2} \mathrm{~T}_{0}$ treatment combination. The highest number of filled grain per panicle of rice (101.77) was recorded with the treatment combination $\mathrm{I}_{1} \mathrm{~T}_{4}$ and the lowest number of filled grain (71.15) was found in $\mathrm{I}_{2} \mathrm{~T}_{0}$ (Alternate wetting and drying with no fertilizer) treatment combination. The highest 1000 grain wt. of rice $(22.50 \mathrm{~g})$ was recorded with the treatment combination $\mathrm{I}_{2} \mathrm{~T}_{4}$ (Alternate wetting and drying $+50 \%$ NPKSZn +5 ton compost/ha). On the other hand, the lowest 1000 grain wt. (19.33) was found in $\mathrm{I}_{2} \mathrm{~T}_{0}$ (Alternate wetting and drying + control treatment) treatment combination. The combined effect of different doses of fertilizer and irrigation on the straw yield of T-Aman rice was insignificant (Table 12). The highest straw yield $(5.13 \mathrm{~kg}$ ) was recorded with the treatment combination $\mathrm{I}_{1} \mathrm{~T}_{1}$ (Continuous flooding $+100 \% \mathrm{~N}_{100} \mathrm{P}_{15} \mathrm{~K}_{45} \mathrm{~S}_{20} \mathrm{Zn}_{2}$ (Recommended). On the other hand, the lowest straw yield ( $3.40 \mathrm{~kg}$ ) was found in $\mathrm{I}_{2} \mathrm{~T}_{0}$ (Alternate wetting and drying + control treatment) treatment combination. The highest grain yield of rice $(2.89 \mathrm{~kg} /$ plot) was recorded with the treatment combination $\mathrm{I}_{2} \mathrm{~T}_{7}$ (Alternate wetting and drying $+70 \%$ NPKSZn +2.1 ton poultry manure/ha). On the other hand, the lowest grain yield $(1.71 \mathrm{~kg} / \mathrm{plot})$ was found in $\mathrm{I}_{2} \mathrm{~T}_{0}$ (Alternate wetting and drying + control treatment) treat- 
ment combination. The yield t/ha was presented in figure 3. Lin., et al. [34] reported that irrigation with organic material application increased yield of rice. In transplanted-Aman rice, the integrated usage of manure and fertilizers culminated in a 2.9-18.3 percent higher crop yield than the single fertilizer treatment [35]. Accord- ing to Bilkis., et al. [35] manure and fertilizers can be used together to produce a sustainable crop yield while maintaining soil fertility. A balanced nutrient application utilizing NPK fertilization is an important management technique for increasing rice-rapeseed production while still protecting the ecosystem.

\begin{tabular}{|l|c|c|c|c|c|c|}
\hline $\begin{array}{l}\text { Treatments } \\
\text { combination }\end{array}$ & $\begin{array}{c}\text { No. of } \\
\text { effective } \\
\text { tillers/hill }\end{array}$ & $\begin{array}{c}\text { Plant } \\
\text { height } \\
\text { (cm) }\end{array}$ & $\begin{array}{c}\text { Panicle } \\
\text { length } \\
\text { (cm) }\end{array}$ & $\begin{array}{c}\mathbf{1 0 0 0} \\
\text { grain } \\
\text { wt. (g) }\end{array}$ & Straw yield & Grain yield \\
\hline $\mathrm{I}_{1} \mathrm{~T}_{0}$ & 7.92 & 106.89 & 23.10 & 19.83 & 4.00 & (kg/plot) \\
\hline $\mathrm{I}_{1} \mathrm{~T}_{1}$ & 8.08 & 121.24 & 25.80 & 20.50 & 5.13 & 2.99 \\
\hline $\mathrm{I}_{1} \mathrm{~T}_{2}$ & 9.50 & 118.06 & 23.45 & 21.83 & 4.87 & 2.57 \\
\hline $\mathrm{I}_{1} \mathrm{~T}_{3}$ & 8.17 & 120.80 & 23.28 & 20.50 & 4.70 & 2.68 \\
\hline $\mathrm{I}_{1} \mathrm{~T}_{4}$ & 8.42 & 114.47 & 24.57 & 20.83 & 4.53 & 2.21 \\
\hline $\mathrm{I}_{1} \mathrm{~T}_{5}$ & 7.92 & 112.56 & 23.44 & 20.83 & 4.83 & 2.36 \\
\hline $\mathrm{I}_{1} \mathrm{~T}_{6}$ & 7.67 & 120.15 & 24.14 & 21.17 & 4.47 & 2.58 \\
\hline $\mathrm{I}_{1} \mathrm{~T}_{7}$ & 8.50 & 118.14 & 24.54 & 21.00 & 4.87 & 2.23 \\
\hline $\mathrm{I}_{2} \mathrm{~T}_{0}$ & 7.25 & 103.96 & 23.01 & 19.33 & 3.40 & 1.71 \\
\hline $\mathrm{I}_{2} \mathrm{~T}_{1}$ & 7.92 & 113.07 & 24.13 & 19.83 & 4.97 & 1.85 \\
\hline $\mathrm{I}_{2} \mathrm{~T}_{2}$ & 8.75 & 118.28 & 23.48 & 20.50 & 5.00 & 2.33 \\
\hline $\mathrm{I}_{2} \mathrm{~T}_{3}$ & 8.00 & 118.28 & 24.43 & 21.67 & 4.83 & 2.41 \\
\hline $\mathrm{I}_{2} \mathrm{~T}_{4}$ & 8.50 & 120.88 & 24.03 & 22.50 & 4.87 & 2.65 \\
\hline $\mathrm{I}_{2} \mathrm{~T}_{5}$ & 7.58 & 120.94 & 32.48 & 20.50 & 4.97 & 2.46 \\
\hline $\mathrm{I}_{2} \mathrm{~T}_{6}$ & 8.08 & 114.38 & 23.92 & 21.33 & 4.60 & 2.52 \\
\hline $\mathrm{I}_{2} \mathrm{~T}_{7}$ & 9.48 & 120.75 & 23.82 & 21.67 & 5.07 & 2.89 \\
\hline $\left.\mathrm{SE}_{2} \pm\right)$ & $n s$ & $n s$ & $n s$ & $n s$ & $n s$ & $\mathrm{~ns}$ \\
\hline & & & & & & \\
\hline
\end{tabular}

Table 10: Combine effect of irrigation with fertilizer and irrigation on yield contributing characters and yield of T-Aman.

According to DMRT, figures with identical letter(s) do not differ significantly while figures with dissimilar letter(s) varied significantly.

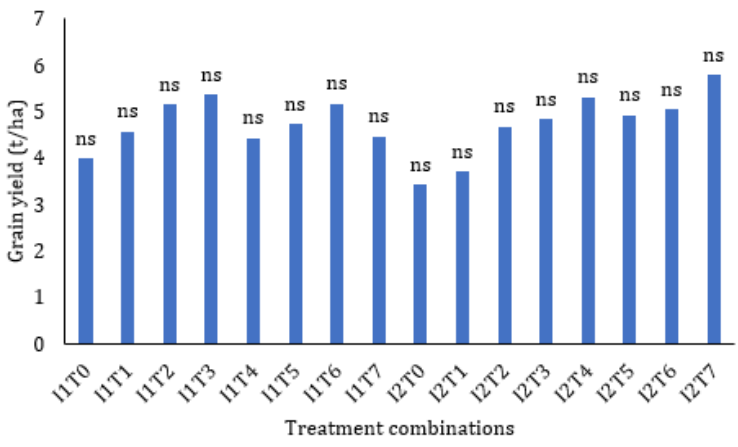

Figure 3: Combine effect of irrigation with different doses of fertilizer and manure on grain yield (t/ha) on Transplanted-Aman rice.
Combine effect of irrigation with fertilizer and irrigation on NPKS concentration of rice grain and straw

The combined effect of different doses of fertilizer and irrigation on NPKS concentration of T-Aman rice was significant (Table 11). The highest $\mathrm{N}$ concentration in grain of rice $(1.400 \%)$ was recorded with the treatment combinations $\mathrm{I}_{2} \mathrm{~T}_{1}$ and $\mathrm{I}_{2} \mathrm{~T}_{6}$ which was statistically similar to $\mathrm{I}_{2} \mathrm{~T}_{7}$ and $\mathrm{I}_{1} \mathrm{~T}_{2}$. On the other hand, the lowest $\mathrm{N}$ concentration in grain of rice $(0.980 \%)$ was found in $\mathrm{I}_{1} \mathrm{~T}_{0}$ treatment combination. The highest $\mathrm{P}$ concentration in grain of rice $(0.290 \%)$ was recorded with the treatment combination $\mathrm{I}_{1} \mathrm{~T}_{3}$ and the lowest $\mathrm{P}$ concentration in grain of rice $(0.173 \%)$ was found in $\mathrm{I}_{1} \mathrm{~T}_{0}$ treatment combination. The highest $\mathrm{K}$ concentration in grain of rice $(0.282 \%)$ was recorded with the treatment combination $\mathrm{I}_{1} \mathrm{~T}_{1}, \mathrm{I}_{1} \mathrm{~T}_{2}$, $\mathrm{I}_{1} \mathrm{~T}_{3}, \mathrm{I}_{1} \mathrm{~T}_{4}, \mathrm{I}_{1} \mathrm{~T}_{6}, \mathrm{I}_{1} \mathrm{~T}_{7}, \mathrm{I}_{2} \mathrm{~T}_{2}, \mathrm{I}_{2} \mathrm{~T}_{4}, \mathrm{I}_{2} \mathrm{~T}_{6}$ and $\mathrm{I}_{2} \mathrm{~T}_{7}$. On the other hand, the lowest $\mathrm{K}$ concentration in grain of rice $(0.197 \%)$ was found in $\mathrm{I}_{2} \mathrm{~T}_{0}$ 
treatment combination. The highest $\mathrm{S}$ concentration in grain of rice $(0.208 \%)$ was recorded with the treatment combination $\mathrm{I}_{1} \mathrm{~T}_{7}$ and the lowest $\mathrm{S}$ concentration in grain of rice $(0.088 \%)$ was found in $\mathrm{I}_{1} \mathrm{~T}_{0}$ treatment combination. The highest $\mathrm{N}$ concentration in $\mathrm{T}$ Aman rice straw $(0.700 \%)$ was recorded in $\mathrm{I}_{1} \mathrm{~T}_{2}$ and $\mathrm{I}_{2} \mathrm{~T}_{6}$ treatment combinations. On the other hand, the lowest $\mathrm{N}$ concentration in straw of rice $(0.457 \%)$ was found in $\mathrm{I}_{1} \mathrm{~T}_{0}$ treatment combination. The highest $\mathrm{P}$ concentration in straw of rice $(0.156 \%)$ was recorded in $\mathrm{I}_{1} \mathrm{~T}_{2}$ treatment combination which was followed (0.147) by $\mathrm{I}_{1} \mathrm{~T}_{5}$ and $\mathrm{I}_{1} \mathrm{~T}_{7}$ treatment combinations. Higher $\mathrm{P}$ was accumulated in rice straw by the application of organic plus inorganic fertilizer with continuous flooded condition, due to higher availability of $\mathrm{P}$ in water logged condition. The highest $\mathrm{K}$ concentration in straw of rice $(1.859 \%)$ was recorded in $\mathrm{I}_{2} \mathrm{~T}_{7}$ with the treatment combination and the second highest level of K concentration (1.538) found in $\mathrm{I}_{2} \mathrm{~T}_{4}$. On the other hand, the lowest $\mathrm{K}$ concentration in straw of rice $(1.090 \%)$ was found in $\mathrm{I}_{1} \mathrm{~T}_{0}$ treatment combination. The highest $\mathrm{S}$ concentration in straw of rice $(0.165 \%)$ was recorded in $\mathrm{I}_{2} \mathrm{~T}_{7}$ treatment combination which was statistically identical with $\mathrm{I}_{1} \mathrm{~T}_{7}$ and $\mathrm{I}_{2} \mathrm{~T}_{2}$. On the other hand, the lowest $\mathrm{S}$ concentration in straw of rice $(0.063 \%)$ was found in $\mathrm{I}_{1} \mathrm{~T}_{0}$ treatment combination which was statistically identical $(0.067 \%)$ with $\mathrm{I}_{1} \mathrm{~T}_{1}$ and $\mathrm{I}_{2} \mathrm{~T}_{6}$ treatment combinations.

\begin{tabular}{|c|c|c|c|c|c|c|c|c|}
\hline \multirow{2}{*}{$\begin{array}{l}\text { Treatments } \\
\text { combination }\end{array}$} & \multicolumn{4}{|c|}{ Concentration (\%) in grain } & \multicolumn{4}{|c|}{ Concentration $(\%)$ in straw } \\
\hline & $\mathbf{N}$ & $\mathbf{P}$ & $\mathbf{K}$ & $\mathbf{S}$ & $\mathbf{N}$ & $\mathbf{P}$ & $\mathbf{K}$ & $\mathbf{S}$ \\
\hline $\mathrm{I}_{1} \mathrm{~T}_{0}$ & $0.980 \mathrm{~d}$ & $0.173 \mathrm{k}$ & 0.218 & 0.088 & 0.457 & $0.104 \mathrm{~h}$ & $1.090 \mathrm{~d}$ & $0.063 \mathrm{~d}$ \\
\hline $\mathrm{I}_{1} \mathrm{~T}_{1}$ & $1.050 \mathrm{~cd}$ & $0.270 \mathrm{~b}$ & 0.282 & 0.196 & 0.630 & $0.144 \mathrm{~b}$ & $1.282 \mathrm{bcd}$ & $0.067 \mathrm{~d}$ \\
\hline $\mathrm{I}_{1} \mathrm{~T}_{2}$ & $1.260 \mathrm{ab}$ & $0.243 \mathrm{~cd}$ & 0.282 & 0.175 & 0.700 & $0.156 \mathrm{a}$ & $1.410 \mathrm{bc}$ & $0.106 \mathrm{abcd}$ \\
\hline $\mathrm{I}_{1} \mathrm{~T}_{3}$ & $1.120 \mathrm{bcd}$ & $0.290 \mathrm{a}$ & 0.282 & 0.150 & 0.490 & $0.134 \mathrm{c}$ & $1.410 \mathrm{bc}$ & $0.121 \mathrm{abcd}$ \\
\hline $\mathrm{I}_{1} \mathrm{~T}_{4}$ & $1.120 \mathrm{bcd}$ & 0.240 de & 0.282 & 0.138 & 0.490 & $0.145 \mathrm{~b}$ & $1.474 \mathrm{bc}$ & $0.081 \mathrm{~cd}$ \\
\hline $\mathrm{I}_{1} \mathrm{~T}_{5}$ & $1.260 \mathrm{ab}$ & $0.237 \mathrm{ef}$ & 0.218 & 0.167 & 0.560 & $0.147 \mathrm{~b}$ & $1.346 \mathrm{bcd}$ & $0.138 \mathrm{abc}$ \\
\hline $\mathrm{I}_{1} \mathrm{~T}_{6}$ & $1.190 \mathrm{bc}$ & $0.247 \mathrm{c}$ & 0.282 & 0.183 & 0.490 & $0.128 \mathrm{~d}$ & $1.346 \mathrm{bcd}$ & $0.144 \mathrm{abc}$ \\
\hline $\mathrm{I}_{1} \mathrm{~T}_{7}$ & $1.153 \mathrm{bc}$ & $0.207 \mathrm{j}$ & 0.282 & 0.208 & 0.537 & $0.146 \mathrm{~b}$ & $1.474 \mathrm{bc}$ & $0.161 \mathrm{ab}$ \\
\hline $\mathrm{I}_{2} \mathrm{~T}_{0}$ & $1.167 \mathrm{bc}$ & $0.177 \mathrm{k}$ & 0.197 & 0.104 & 0.497 & 0.122 def & $1.474 \mathrm{bc}$ & $0.069 \mathrm{~d}$ \\
\hline $\mathrm{I}_{2} \mathrm{~T}_{1}$ & $1.400 \mathrm{a}$ & $0.210 \mathrm{ij}$ & 0.218 & 0.196 & 0.630 & $0.114 \mathrm{~g}$ & $1.410 \mathrm{bc}$ & $0.125 \mathrm{abcd}$ \\
\hline $\mathrm{I}_{2} \mathrm{~T}_{2}$ & $1.120 \mathrm{bcd}$ & $0.217 \mathrm{~h}$ & 0.282 & 0.158 & 0.560 & $0.124 \mathrm{de}$ & $1.346 \mathrm{bcd}$ & $0.161 \mathrm{ab}$ \\
\hline $\mathrm{I}_{2} \mathrm{~T}_{3}$ & $1.260 \mathrm{ab}$ & $0.240 \mathrm{de}$ & 0.218 & 0.192 & 0.630 & $0.137 \mathrm{c}$ & $1.218 \mathrm{~cd}$ & $0.136 \mathrm{abc}$ \\
\hline $\mathrm{I}_{2} \mathrm{~T}_{4}$ & $1.050 \mathrm{~cd}$ & $0.223 \mathrm{~g}$ & 0.282 & 0.196 & 0.560 & $0.119 \mathrm{efg}$ & $1.538 \mathrm{~b}$ & $0.098 \mathrm{bcd}$ \\
\hline $\mathrm{I}_{2} \mathrm{~T}_{5}$ & $1.120 \mathrm{bcd}$ & $0.213 \mathrm{hi}$ & 0.218 & 0.196 & 0.560 & $0.122 \mathrm{def}$ & $1.282 \mathrm{bcd}$ & $0.138 \mathrm{abc}$ \\
\hline $\mathrm{I}_{2} \mathrm{~T}_{6}$ & $1.400 \mathrm{a}$ & $0.233 \mathrm{f}$ & 0.282 & 0.163 & 0.700 & $0.121 \mathrm{ef}$ & $1.410 \mathrm{bc}$ & $0.067 \mathrm{~d}$ \\
\hline $\mathrm{I}_{2} \mathrm{~T}_{7}$ & $1.273 \mathrm{ab}$ & $0.227 \mathrm{~g}$ & 0.282 & 0.200 & 0.660 & $0.117 \mathrm{fg}$ & $1.859 \mathrm{a}$ & $0.165 \mathrm{a}$ \\
\hline SE $( \pm)$ & 0.045 & 0.010 & 0.013 & 0.024 & 0.0402 & 0.0055 & 0.0736 & 0.0172 \\
\hline
\end{tabular}

Table 11: Combine effect of irrigation with fertilizer and irrigation on NPKS concentration in T-Aman rice grain and straw. According to DMRT, figures with identical letter(s) do not differ significantly while figures with dissimilar letter(s) varied significantly. 
Combine effect of irrigation with fertilizer and irrigation on NPKS uptake by rice grain and straw

The combined effect of different doses of fertilizer and irrigation on NPKS uptake by T-Aman rice grain and straw were insignificant (Table 12). The highest $\mathrm{N}$ uptake by grain $(0.035 \mathrm{~kg} / \mathrm{plot})$ was recorded with the treatment combination $\mathrm{I}_{2} \mathrm{~T}_{6}$. On the other hand, the lowest $\mathrm{N}$ uptake by grain of rice $(0.021 \mathrm{~kg} / \mathrm{plot})$ was found in $\mathrm{I}_{1} \mathrm{~T}_{0}$ treatment combination. The highest $\mathrm{P}$ uptake by grain $(0.007$ $\mathrm{kg} / \mathrm{plot}$ ) was recorded with the treatment combination $\mathrm{I}_{1} \mathrm{~T}_{3}$. On the other hand, the lowest $\mathrm{P}$ uptake by grain of rice $(0.003 \mathrm{~kg} / \mathrm{plot})$ was found in $\mathrm{I}_{1} \mathrm{~T}_{0}$ treatment combination. The highest $\mathrm{K}$ uptake by grain $(0.017 \mathrm{~kg} /$ plot $)$ was recorded in $\mathrm{I}_{1} \mathrm{~T}_{2}$ and at $\mathrm{I}_{2} \mathrm{~T}_{4}$ treatment combinations. On the other hand, the lowest $\mathrm{K}$ uptake by grain of rice $\left(0.010 \mathrm{~kg} /\right.$ plot was found in $\mathrm{I}_{2} \mathrm{~T}_{0}$ treatment combination. The highest $\mathrm{S}$ uptake by grain $(0.006 \mathrm{~kg} / \mathrm{plot})$ was recorded in $\mathrm{I}_{2} \mathrm{~T}_{7}$ treatment combination and the lowest $\mathrm{S}$ uptake by grain of rice $(0.002$ $\mathrm{kg} /$ plot) was found in $\mathrm{I}_{1} \mathrm{~T}_{0}$ treatment combination. In case of straw, the highest $\mathrm{N}$ uptake by straw $(0.034 \mathrm{~kg} / \mathrm{plot})$ was recorded in $\mathrm{I}_{1} \mathrm{~T}_{2}$ treatment combination and the lowest $\mathrm{N}$ uptake by straw of rice $(0.022 \mathrm{~kg} / \mathrm{plot})$ was found in $\mathrm{I}_{2} \mathrm{~T}_{0}, \mathrm{I}_{1} \mathrm{~T}_{4}, \mathrm{I}_{1} \mathrm{~T}_{6}$ and $\mathrm{I}_{2} \mathrm{~T}_{0}$ treatment combinations. The highest $\mathrm{P}$ uptake by straw $(0.007 \mathrm{~kg} / \mathrm{plot})$ was recorded with the treatment combination $\mathrm{I}_{1} \mathrm{~T}_{7}$ which was statistically identical $(0.007 \mathrm{~kg} /$ plot $)$ with $\mathrm{I}_{2} \mathrm{~T}_{3}$ treatment combination and the lowest $\mathrm{P}$ uptake by straw of rice $(0.004 \mathrm{~kg} / \mathrm{plot})$ was found in $\mathrm{I}_{1} \mathrm{~T}_{0}$ and $\mathrm{I}_{2} \mathrm{~T}_{0}$ treatment combinations. The highest $\mathrm{K}$ uptake by straw $(0.094 \mathrm{~kg} / \mathrm{plot})$ was recorded with the treatment combination $\mathrm{I}_{2} \mathrm{~T}_{7}$ and the lowest $\mathrm{K}$ uptake by straw of rice was $(0.043 \mathrm{~kg} / \mathrm{plot})$ with $\mathrm{I}_{1} \mathrm{~T}_{0}$ treatment combination. The highest $\mathrm{S}$ uptake by straw $(0.008$ $\mathrm{kg} / \mathrm{plot}$ ) was recorded in $\mathrm{I}_{1} \mathrm{~T}_{7}, \mathrm{I}_{2} \mathrm{~T}_{2}$ and $\mathrm{I}_{2} \mathrm{~T}_{7}$ treatment combinations. On the other hand, the lowest $\mathrm{S}$ uptake by straw of rice $[0.02$ $\mathrm{kg} / \mathrm{plot}$ ) was found in $\mathrm{I}_{1} \mathrm{~T}_{0}$ treatment combination.

\begin{tabular}{|l|c|c|c|c|c|c|c|c|}
\hline \multirow{2}{*}{$\begin{array}{l}\text { Treatments } \\
\text { combination }\end{array}$} & \multicolumn{4}{|c|}{ Uptake by grain (kg/plot) } & \multicolumn{4}{c|}{ Uptake by straw (kg/plot) } \\
\cline { 2 - 9 } & $\mathbf{N}$ & $\mathbf{P}$ & $\mathbf{K}$ & $\mathbf{S}$ & $\mathbf{N}$ & $\mathbf{P}$ & $\mathbf{K}$ & $\mathbf{S}$ \\
\hline $\mathrm{I}_{1} \mathrm{~T}_{0}$ & 0.021 & $0.003 \mathrm{e}$ & 0.014 & 0.002 & $0.023 \mathrm{fg}$ & $0.004 \mathrm{bc}$ & 0.043 & 0.002 \\
\hline $\mathrm{I}_{1} \mathrm{~T}_{1}$ & 0.023 & $0.006 \mathrm{ab}$ & 0.016 & 0.005 & $0.028 \mathrm{e}$ & $0.007 \mathrm{a}$ & 0.066 & 0.003 \\
\hline $\mathrm{I}_{1} \mathrm{~T}_{2}$ & 0.032 & $0.006 \mathrm{ab}$ & 0.017 & 0.005 & $0.034 \mathrm{a}$ & $0.008 \mathrm{a}$ & 0.069 & 0.005 \\
\hline $\mathrm{I}_{1} \mathrm{~T}_{3}$ & 0.030 & $0.007 \mathrm{a}$ & 0.014 & 0.004 & $0.023 \mathrm{fg}$ & $0.006 \mathrm{a}$ & 0.066 & 0.006 \\
\hline $\mathrm{I}_{1} \mathrm{~T}_{4}$ & 0.025 & $0.005 \mathrm{abcde}$ & 0.013 & 0.003 & $0.022 \mathrm{~g}$ & $0.007 \mathrm{a}$ & 0.067 & 0.004 \\
\hline $\mathrm{I}_{1} \mathrm{~T}_{5}$ & 0.030 & $0.006 \mathrm{abc}$ & 0.016 & 0.003 & $0.027 \mathrm{e}$ & $0.007 \mathrm{a}$ & 0.065 & 0.007 \\
\hline $\mathrm{I}_{1} \mathrm{~T}_{6}$ & 0.031 & $0.005 \mathrm{abcd}$ & 0.016 & 0.005 & $0.022 \mathrm{~g}$ & $0.006 \mathrm{abc}$ & 0.060 & 0.006 \\
\hline $\mathrm{I}_{1} \mathrm{~T}_{7}$ & 0.026 & $0.004 \mathrm{cde}$ & 0.014 & 0.005 & $0.025 \mathrm{f}$ & $0.007 \mathrm{a}$ & 0.072 & 0.008 \\
\hline $\mathrm{I}_{2} \mathrm{~T}_{0}$ & 0.022 & $0.003 \mathrm{de}$ & 0.010 & 0.002 & $0.022 \mathrm{~g}$ & $0.004 \mathrm{c}$ & 0.050 & 0.003 \\
\hline $\mathrm{I}_{2} \mathrm{~T}_{1}$ & 0.029 & $0.005 \mathrm{bcde}$ & 0.014 & 0.004 & $0.031 \mathrm{bc}$ & $0.006 \mathrm{abc}$ & 0.281 & 0.006 \\
\hline $\mathrm{I}_{2} \mathrm{~T}_{2}$ & 0.026 & $0.005 \mathrm{bcde}$ & 0.015 & 0.004 & $0.028 \mathrm{de}$ & $0.006 \mathrm{ab}$ & 0.067 & 0.008 \\
\hline $\mathrm{I}_{2} \mathrm{~T}_{3}$ & 0.030 & $0.006 \mathrm{ab}$ & 0.015 & 0.005 & $0.031 \mathrm{bc}$ & $0.007 \mathrm{a}$ & 0.059 & 0.006 \\
\hline $\mathrm{I}_{2} \mathrm{~T}_{4}$ & 0.028 & $0.005 \mathrm{bcde}$ & 0.017 & 0.005 & $0.027 \mathrm{e}$ & $0.006 \mathrm{abc}$ & 0.075 & 0.005 \\
\hline $\mathrm{I}_{2} \mathrm{~T}_{5}$ & 0.028 & $0.005 \mathrm{bcde}$ & 0.014 & 0.005 & $0.028 \mathrm{e}$ & $0.006 \mathrm{abc}$ & 0.064 & 0.007 \\
\hline $\mathrm{I}_{2} \mathrm{~T}_{6}$ & 0.035 & $0.006 \mathrm{ab}$ & 0.016 & 0.004 & $0.032 \mathrm{ab}$ & $0.006 \mathrm{abc}$ & 0.065 & 0.003 \\
\hline $\mathrm{I}_{2} \mathrm{~T}_{7}$ & 0.031 & $0.006 \mathrm{ab}$ & 0.016 & 0.006 & $0.030 \mathrm{~cd}$ & $0.006 \mathrm{ab}$ & 0.094 & 0.008 \\
\hline $\left.\mathrm{SE}_{2} \pm\right)$ & 0.0023 & 0.0005 & $\mathrm{~ns}$ & $\mathrm{~ns}$ & 0.0024 & 0.0003 & $\mathrm{~ns}$ & $\mathrm{~ns}$ \\
\hline
\end{tabular}

Table 12: Combine effect of irrigation with fertilizer and irrigation on NPKS uptake by T-Aman rice grain and straw.

According to DMRT, figures with identical letter(s) do not differ significantly while figures with dissimilar letter(s) varied significantly. 


\section{Conclusion}

From the findings of the result of the research we can be concluded that irrigation had no significant effect on yield and yield contributing characters and alternate wetting and drying is preferable than flood irrigation. The use of inorganic fertilizer plus manure was higher than inorganic fertilizer. The application of $70 \%$ NPKSZn plus 2.1 ton poultry manure/ha and alternate wetting and drying was most favorable for improving yield contributing characters and yield of T-Aman. For recommendation, another combination of NPKS and others organic manures with different water management may be included for further study.

\section{Acknowledgements}

The authors would like to express sincere gratitude to the department of Soil Science, Sher-e-Bangla Agricultural University, Dhaka, Bangladesh for the logistic supports in this research.

\section{Conflict of Interest}

None.

\section{Bibliography}

1. Welch RM., et al. "A new paradigm for world agriculture: meeting human needs: productive, sustainable, nutritious". Field crops research 60.1-2 (1999): 1-10.

2. BBS. Bangladesh Bureau of Statistics, Statistical Year Book of Bangladesh, Agriculture Statistical Wing, Ministry of Planning, Government of Peoples Republic of Bangladesh, Bangladesh (2019): 121.

3. FAO. Food and Agricultural Organization, Yearbook of Production, FAO Statistics Division, Rome, Italy (2015): 605-607.

4. Chukwuka KS. "Soil fertility restoration techniques in sub-Saharan Africa using organic resources". African Journal of Agricultural Research 4.3 (2009): 144-150.

5. Islam ATM. "Evaluation of mixed and complex fertilizers for wet land rice". Pakistan Journal of Scientific and Industrial Research 37.9 (1994): 378-381.

6. Haque Sk A. "Salinity problems and crop production in coastal regions of Bangladesh". Pakistan Journal of Botany 38.5 (2006): 1359-1365.

7. Iqbal A., et al. "Organic manure coupled with inorganic fertilizer: An approach for the sustainable production of rice by improving soil properties and nitrogen use efficiency". Agronomy 9.10 (2019): 651.
8. Uddin MJ., et al. "Land inundation and cropping intensity influences on organic carbon in the agricultural soils of Bangladesh". Catena 178 (2019): 11-19.

9. Islam MS. "Use of bioslurry as organic fertilizer in Bangladesh agriculture". In Prepared for the presentation at the international workshop on the use of bioslurry domestic biogas programme. bangkok, thailand, (2006): 3-16.

10. Hasanuzzaman M., et al. "Plant growth characters and productivity of wetland rice (Oryza sativa L.) as affected by application of different manures". Emirates Journal of Food and Agriculture (2010): 46-58.

11. Chen JH. "The combined use of chemical and organic fertilizers and/or biofertilizer for crop growth and soil fertility". International workshop on sustained management of the soilrhizosphere system for efficient crop production and fertilizer use. Land Development Department Bangkok Thailand 16.20 (2006).

12. Miah SS and SN Swamy. "Effect of time of $\mathrm{N}$ application on yield and yield attributes of rice (Oryza sativa) cultivars". Journal of Ecology and Environment 21.2 (1994): 411-413.

13. Shirani H., et al. "Effects of farmyard manure and tillage systems on soil physical properties and corn yield in central Iran". Soil and tillage research 68.2 (2002): 101-108.

14. Yang C., et al. "Rice root growth and nutrient uptake as influenced by organic manure in continuously and alternately flooded paddy soils". Agricultural Water Management 70.1 (2004): 67-81.

15. FAO. Food and Agricultural Organization and UNDP. United Nations Development Programme. Land Resources Appraisal of Bangladesh for Agricultural Development. Report 2, Agroecological Region Bangladesh. (1988): 472-496.

16. Gomez KA and AA Gomez. "Statistical Procedures for Agricultural Research". 2nd ed. John Wiley and Sons. New York (1984).

17. Nayak DR., et al. "Long-term application of compost influences microbial biomass and enzyme activities in a tropical Aeric Endoaquept planted to rice under flooded condition". Soil Biology and Biochemistry 39.8 (2007): 1897-1906.

18. Rahman MS., et al. "Effect of cowdung, poultry manure and urea-N on the yield and nutrient uptake of BRRI dhan 29". Bangladesh Research Journal 2 (2009): 552-558. 
19. Reddy AS., et al. "Effect of organic sources of plant nutrients in conjunction with chemical fertilizers on growth, yield and quality of rice". Research on Crops 5.2/3 (2004): 159-161.

20. Aga FA., et al. "Effect of different levels of compost on growth and yield of rice". Journal of Environment and Ecology 22.2 (2004): 353-356.

21. Babu S., et al. "Effect of organic and inorganic manures on growth and yield of rice". Agricultural Science Digest 21.4 (2001): 232-234.

22. Reddy BGM., et al. "Response of rice to poultry manure and graded levels of NPK under irrigated conditions". Oryza 42.2 (2005): 109.

23. Mahmud A., et al. "Effect of organic and inorganic fertilizer on the growth and yield of rice (Oryza sativa L)". Nature Science 14.2 (2016): 45-54.

24. Miah MAM., et al. "Integrated nutrient management for improving soil health and rice production". Proc. of twenty first BRRI-DAE joint workshops on bridging the rice yield gap for food security. BRRI, Gazipur, Bangladesh (2006).

25. Miah MAM., et al. "Nutrient management for different rice ecosystem". Proc. of the workshop on modern rice cultivation in Bangladesh. BRRI, Gazipur, Bangladesh. (2004).

26. Xie Z., et al. "Substitution of fertilizer-N by green manure improves the sustainability of yield in double-rice cropping system in south China". Field Crops Research 188 (2016): 142-149.

27. Azim UH. "Effect of different doses of N, P, K \& S on the yield of BR11 variety of rice". Rural Development Academy, Bogra (1999): 15-20.

28. Haque SA. "Nutrient requirements of wet land rice production". Proc. Int. Symp. On Paddy soils, September 15-19, Beijing, China Academia Sinica (1999): 281-282.

29. Singh R., et al. "Effect of fertilizers, FYM and row spacing on transplanted rice”. Crop Research-Hisar- 22.2 (2001): 295-296.

30. Maharjan M., et al. "Effect of land use and management practices on microbial biomass and enzyme activities in subtropical top-and sub-soils". Applied Soil Ecology 113 (2017): 22-28.

31. Sengar SS., et al. "Effect of nutrient management on rice (Oryza sativa) in rainfed lowland of southeast Madhya Pradesh". Indian Journal of Agronomy 45.2 (2000): 315-322.
32. Rahman MA. "Integrated use of fertilizer and manure for crop production in wheat-rice and rice-rice cropping patterns". Ph. D. Thesis. Department of Soil Science, Bangladesh Agricultural University, Mymensingh, Bangladesh (2001): 125.

33. Duhan BS and M Singh. "Effect of green manuring and nitrogen on yield of and uptake of micronutrients by rice". Journal of the Indian Society of Soil Science 50.2 (2002): 178-180.

34. Lin X., et al. "Effects of water management and organic fertilization with SRI crop practices on hybrid rice performance and rhizosphere dynamics". Paddy and Water Environment 9.1 (2011): 33-39.

35. Bilkis S., et al. "Integrated use of manure and fertilizers increases rice yield, nutrient uptake and soil fertility in the borofallow-t.aman rice cropping pattern". SAARC Journal of Agriculture 15.2 (2017): 147-147.

36. Yousaf M., et al. "Effects of fertilization on crop production and nutrient-supplying capacity under rice-oilseed rape rotation system". Scientific reports 7.1 (2017): 1-9.

\section{Assets from publication with us}

- Prompt Acknowledgement after receiving the article

- Thorough Double blinded peer review

- Rapid Publication

- Issue of Publication Certificate

- High visibility of your Published work

Website: www.actascientific.com/

Submit Article: www.actascientific.com/submission.php

Email us: editor@actascientific.com

Contact us: +919182824667 